\title{
Practical Aspects of Appointment of Judicial Expertise in the Field of Intellectual Property (Expertise of Copyright Objects and Related Rights, Articles, Computer Programs and Databases, Implementation of Phonograms, Videos, Programs (Transfer) of Loans Organizations)
}

\begin{abstract}
Kofanov Andrii
Legal Advisor to the Council of Europe Programme "Decentralization and Territorial Consolidation in Ukraine”, PhD of Juridical Sciences, Associate Professor, Professor of Department of Forensic Support and Forensic Expertise of the National Academy of Internal Affairs, Kiev, Ukraine ORCID ID 0000-0002-5242-2518 kofanov_andrey@ukr.net

\section{Atamanchuk Volodymyr}

PhD of Juridical Sciences, Chief of Department of Forensic Support and Forensic Expertise of the National Academy of Internal Affairs, Kiev, Ukraine https://orcid.org/0000-0002-1464-7871 atamanchykvlad@ukr.net

\section{Pavlovska Nataliia}

PhD of Juridical Sciences, Associate Professor, Professor of Department of Civil Law and Process of the National Academy of Internal Affairs, Kiev,

Ukraine ORCID ID 0000-0003-3311-0364 wwwpav@gmail.com
\end{abstract}

\section{Kulyk Maryna}

PhD of Juridical Sciences, Associate Professor of Forensic Support and Forensic Expertise of the National Academy of Internal Affairs, Kiev, Ukraine ORCID ID 0000-0003-1373-6749 coolss777@ukr.net

\section{Tereshchenko Yuliia}

PhD of Juridical Sciences, Professor of Criminal Law Disciplines and Operative and Investigative Activities of the Precarpathian Department of the National

Academy of Internal Affairs, Kyiv, Ukraine ORCID ID 0000-0002-5353-0887 vladysikter@ukr.net

\footnotetext{
Abstract

The object of examination of objects of copyright and related rights is the actual data belonging to the properties of material and non-material (information) objects. These data are established on the basis of special knowledge in the field of copyright and related rights, strictly in accordance with the requirements of the law and may have probative value in criminal, civil, economic and administrative cases. The features of an expert
} 
examination by the new Criminal Procedure Code of Ukraine are carried out in the article. The procedure of judicial examination in intellectual property rights sphere in criminal proceedings is analyzed and shown in accordance with current legislation.

Keywords: expertise of copyright objects and related rights, articles, computer programs and databases, implementation of phonograms, videos, programs of loans organizations.

Introduction Objects of examination of copyright and related rights are: literary, written works of fiction, journalistic, scientific, technical or other nature (books, pamphlets, articles, etc.); speeches, lectures, sermons and other oral works; computer programs; databases, if they are the result of intellectual activity by selection or ordering of their constituent parts; musical works with text and without text; dramatic, musical and dramatic works, pantomimes, choreographic and other works created for the stage show, and their production; audiovisual works; works of fine art; works of architecture, urban development and garden art; photographic works, including works, executed in ways similar to photography; works of applied art, including: works of decorative weaving, ceramics, carvings, pouring out of art glass, jewelry, if they are not protected by the laws of Ukraine on the legal protection of industrial property objects; illustrations, maps, plans, drawings, sketches, plastic works relating to geography, geology, topography, engineering, architecture and other fields of activity; stage workings, folklore processing, suitable for stage show; derivative works; collections of works of folklore, encyclopedias and anthologies, collections of ordinary data, and other compositions, provided that they are the result of creative work in the selection, coordination or streamlining of content without infringing the copyrights of the works included in them as an integral part; any methods of performing literary, dramatic, musical, musical-dramatic, choreographic, folklore and other works; phonograms; videograms; broadcast programs, etc.

Examination of the objects of copyright and related rights are solved by two main groups of tasks: identification and diagnostic. Identification study is to establish the identity of objects. It includes identification: a work for the use of plagiarism; persons who created the work; the work by its parts (or part); source of the work; according to the requirements for the production and distribution of copies of the work; equipment by which the carrier of the work (its packaging) is manufactured. The diagnostic study consists in revealing the essence of the particular taken for the study of the object by its features by referring it to a particular type, class, and the like. This includes installing: the security of research objects; originality of the 
name of the work, parts of the work and legally significant elements of the work; kind of object of copyright (related rights) and its nature; establishing the fact of the change of the work and its method; establishing the fact of using the product and its method; determination of signs of counterfeiting copies of the work [1].

Concerning one research object, both identification and diagnostic tasks can be solved. Approximate list of issues that are solved during the examination of objects of copyright and related rights: 1). Does the work "XXX" have signs of a creative character, is it a result of creative work? 2). Is the work "XXX" a subject of copyright (related rights) and, if so, which type of object does it belong to? 3). Is the title "XXX" original? 4). Are there copyright objects (related rights) on the bearer "XXX" and, if so, which types of objects do they belong to? 5). Does the copy of the work contain a sign of counterfeiting? 6). Is there a fact of the use of the work (fragment of the work and the original title of the work) "XXX" in the work "UUU"? If so, is there such use of plagiarism? 7). Was the product "XXX" changed by processing, adapting, arranging, or otherwise? 8). Was the product "XXX" used as the basis and source of the work "UCU", in particular, by borrowing ideas, strategies, structures? If so, what exactly is used, borrowed from the work "XXX" when compiling the work "UUU"? 9). Is there a designation "XXX" that is located on the object "A" by reproducing a work "UUU" or a part of it? 10). Is there a "UUU" image placed on the object under investigation, reproducing the character of the work "XXX"? 11). Is the work "XXX" an integral part of the audiovisual work "UUU"? 12). Has there been playback (direct and / or indirect) of performances of "XXX" in a phonogram (videogram) "UUU"? 13). Was there a use of the product in the amount justified by the goal? 14). Is it possible to establish a stylistic affinity for "XXX" and "UUU"? 15). Was the computer program "XXX" decompiled (transformed from the object code into the source text) in order to interact with the computer program "UUU"? 16). Were there any use of the XXX program for any other purpose (indicated with) except for archiving or replacing the purchased copy of "XXX"? 17). Are the carriers of the product (its packaging) manufactured using the same equipment? [3, 4]

In practice, there are not unusual cases when the initiators of the appointment of examinations and studies in this area raises questions about who is the copyright holder of works or phonograms recorded on investigative copies of counterfeit products (who owns copyright and related rights?). The essence of this issue is of a purely legal nature, since the 
contractual relations of the right holders with legal entities or individuals are of a dynamic nature in time, territory and circle of individuals, does not require special expertise of the expert and is subject to the establishment of operational and investigative units.

In the decision (decree) on the appointment of the examination, it is necessary to indicate the essence of the case, on the basis of which the expert was appointed; be sure to make a reference to the protocol, indicating the quantitative and qualitative composition of the withdrawn products and carefully describe the package. Together with the decision (decree) on the appointment of an expert assessment, the expert shall be provided with a complete list of research objects, including the electronic version, which are properly packed and sealed, which ensures their storage and integrity from the moment of withdrawal until the examination. Examination related to commercial (branded) denominations, trademarks (trademarks for goods and services), geographic indications.

Objects of research are signs for goods and services, designations affixed to the product, packaging containing such a product, a sign, associated with it, a label, a stylus, a tag or other item attached to a product, commercial (branded) name, indicating the origin of the goods and other materials of the case, which are investigated by the expert for the decision of questions raised to the expert with application of special knowledge.

The subject of examination is the actual data that belong to the properties of material and intangible (information) objects, a comprehensive study of which provides an opportunity to determine their security and other circumstances of the case, relevant for the bodies of pretrial investigation and court.

Issues solved in research related to the protection of rights to marks for goods and services, brand names, indication of the origin of goods, etc.

Inconsistency with the conditions of granting legal protection

- Is there a sign for goods and services for the certificate of Ukraine No. 000 that does not have a distinctive ability and has not acquired such a result as a result of its use?

- Is a sign for goods and services for the certificate of Ukraine No 000 only for signs that are commonly used as a designation of goods and services of a certain type?

- Is the mark for goods and services for the certificate of Ukraine No 000 only for signs or data that are descriptive when used in relation to them in relation to the goods and services indicated in the application, in particular, indicate the type, quality, composition, 
quantity, properties, destination, value of goods and services, place and time of manufacture or sale of goods or provision of services?

- Is there a mark for goods and services for the certificate of Ukraine No. 000 deceitful or deceitful as to the goods, services or person who produces the goods or renders the service?

- Is there a sign for goods and services for the certificate of Ukraine No. 000 only from symbols that are commonly used symbols and terms?

- Is there a mark for goods and services for the certificate of Ukraine No. 000 in such a way that it reflects only the form due to the natural state of the product or the need to obtain a technical result, or which provides the goods with essential value?

- Does the mark for goods and services on the certificate of Ukraine number 000 unobserved elements? [3, 4]

Issuance of a certificate as a result of submission of an application in violation of the rights of third parties

- Is there a sign for goods and services for the certificate of Ukraine No. 111 identical or similar to the extent that it can be confused with a sign for goods and services under the certificate of Ukraine No. 000 (previously registered or filed for registration in Ukraine on behalf of another person for the same or related products and services)?

- Is there a sign for goods and services for the certificate of Ukraine No. 000 identical or similar to the extent that it can be confused with the mark on the certificate No. 222 (a sign of another person, if this sign is protected without registration on the basis of international agreements to which Ukraine is a party, in particular, a sign recognized as well-known in accordance with Article 6 of the Paris Convention for the Protection of Industrial Property)?

- Is a mark for goods and services under the certificate of Ukraine No. 000 identical or similar to the extent that it can be confused with the trademark "XXX" (known in Ukraine and belongs to another person who has been entitled to it before the date of submission to the Office of an application for such themselves or related products and services)?

- Is there a sign for goods and services for the certificate of Ukraine No. 000 identical or similar to the extent that it can be confused with the qualified indication of the origin of the goods "XXX" (protected in accordance with the Law of Ukraine "On the protection of rights to indicate the origin of goods")? 
- Is there a mark for goods and services for the certificate of Ukraine No. 000 identical or similar to the extent that it can be confused with the "XXX" (registered in accordance with the established order) conformity marking (certification mark)?

- Does the mark for goods and services reproduce for the certificate of Ukraine No. 000 the title (quotation, character) of the well-known work of science (literature and art) in Ukraine "XXX"?

- Does the trademark for goods and services reproduce the certificate of Ukraine No. 000 of the work of art "XXX" and its fragments?

- Does the trademark for goods and services on the certificate of Ukraine number? 000 surname (name, pseudonym and derivatives from them, portrait, facsimile) of a person known in Ukraine?

- Has the mark for goods and services evolve according to the certificate of Ukraine No. 000 in the designation, which became commonly used as a designation of goods and services of a certain type?

Use of the mark in the form of a registered mark

- Is there a designation "XXX" (affixed to the product, the packaging containing such a product, a sign, associated with it, a label, a stylus, a tag or other item attached to the item, applied at the time of the offer and the provision of any service, for which the sign is registered; applied in business documentation or in advertising and on the Internet, in the domain name of the enterprise "A") using the registered trademark for goods and services under the certificate of Ukraine No. 000 concerning the goods and services indicated on the certificate?

- Is there a designation "XXX" (affixed to the product, the packaging containing such a product, a sign, associated with it, a label, a stylus, a tag or other item attached to the item, applied at the time of the offer and the provision of any service, for which the mark is registered; applied in business documentation or in advertising and on the Internet, in the domain name of the enterprise "A") using the registered trade mark for goods and services under the certificate of Ukraine No. 000 concerning goods and services related to the certificates given, which you can weave Are you deceived about the person who produces the goods or renders services? 
Use of a mark in a form different from the registered mark only by individual elements, if it does not change the marking as a whole

- Is there a designation "XXX" (affixed to the product, the packaging containing such a product, a sign, associated with it, a label, a stylus, a tag or other item attached to the item, applied at the time of the offer and the provision of any service, for which the mark is registered; applied in the business documentation or in advertising and on the Internet, in the domain name of the enterprise "A") is similar to the registered trade mark for goods and services under the certificate of Ukraine No. 000, in relation to the goods and services given in the certificate, as a result of which the sign and the sign can be ignored atm?

- Is there a designation "XXX" (affixed to the product, the packaging containing such a product, a sign, associated with it, a label, a stylus, a tag or other item attached to the item, applied at the time of the offer and the provision of any service, for which the sign is registered; applied in business documentation or in advertising and on the Internet, in the domain name of the enterprise "A") is similar to the registered mark for goods and services under the certificate of Ukraine No. 000, concerning goods and services related to the certificates given in the certificate, so that can enter in about Come on people, which produces goods or provides services to, or may be confused?

Violation of rights regarding the brand (commercial) name and qualified indication of the origin of goods

- Are the information in the case file indicating that the commercial (firm) name "XXX" misleads consumers about its true business?

- Is there a commercial (firm) name "XXX" for the identical registered trade mark for goods and services under the certificate of Ukraine No. 000 in relation to the goods and services listed on the certificate?

- Is there a commercial (firm) name "XXX" for the identical registered trademark for goods and services under the certificate of Ukraine No. 000 concerning goods and services related to the certificates given, which may lead to confusion as to the person who produces the goods or provides services?

- Is the commercial (firm) name "XXX" similar to a registered trademark for goods and services under the certificate of Ukraine No. 000, in relation to the goods and services 
listed in the certificate, which may lead to confusion between these designations and the mark?

- Is the commercial (firm) name "XXX" similar to the registered trademark for goods and services under the certificate of Ukraine No. 000 concerning goods and services related to the certificates given in such a way as to mislead the person who produces the goods or provides services, or may be confused?

- Are the same commercial (branded) denominations "XXX" and "XXX" (belonging to different persons) to mislead consumers about the goods (services) they produce (sold, provided)?

- Is a mark for goods and services under the certificate of Ukraine No. 000 identical or similar to the extent that it can be confused with the trademark "XXX" (known in Ukraine and belongs to another person who has been entitled to it before the date of submission to the Office of an application for such themselves or related products and services)?

- Does the sign "XXX" have signs that characterize it as a qualified indication of the origin of the goods?

- Does the symbol "XXX" with a qualified indication of the origin of the goods coincide? $[3,4]$

The practice of appointing forensic examinations of intellectual property objects testifies to the difficulty in distinguishing the "question of fact" from (and) the "question of law", and as a consequence, the formulation of issues of a legal nature, the resolution of which is determined by the current legislation as the competence of the investigation and the court. For example, the question "Does the sign for goods and services comply with the certificate of Ukraine No. 000 on the conditions of security?" can be resolved in the following volume "Is the mark for goods and services for the certificate of Ukraine No. 000 only for signs that are commonly used symbols and terms? " or to indicate any other ground for refusal to register the mark for goods and services [2]. The main drawback of the preparation of materials in this area is their incompleteness, that is, for expert examination at the disposal of the expert, not all necessary and sufficient materials are provided, in particular: copies of documents issued by public authorities do not have notarized certification by the law (for example, copies of certificates are often submitted not properly certified); the absence of 
through-numbering of the case sheets or errors in their numbering; absence of samples (for example, full-color packaging samples, labels).

Thus, the bodies of pre-trial investigation and courts do not demand and submit to the expert institutions application materials, as well as reports on information searches. The materials of the applications are necessary in order to determine whether the object for which the security document was issued, the declared object, as well as for studying the issues regarding the possible grounds for refusal of registration. Not always copies of documents are presented in proper form. For example, certificates for signs for goods and services are presented in the form of photocopies. This does not matter if the sign is registered in black and white. However, if a sign has received legal protection in a certain combination of colors, the image provided for examination of the image must be color-coded.

Conclusions Intellectual property today is a powerful factor in progress, which largely determines the trends of the modern world. Therefore, the protection of intellectual property rights is one of the most important tasks of the state and society, which seeks to take a worthy place in the world community.

\section{References}

1. Praktichni aspekti priznachennia sudovoï ekspertizi u sferi intelektual'noï vlasnosti. [Practical Aspects of Appointment of Forensic Expertise in the Field of Intellectual Property] Retrieved from: http://bsm.com.ua/2011-08-07-02-51-49/item/197-biznes-ibezopasnost-2-2018

2. Kofanov, A., Voloshin, O. \& Kravchuk, O. (2012). Kryminalistychne doslidzhennja ob jektiv intelektual'noi' vlasnosti [Forensic study of intellectual property objects]. Course of lectures, Khmelnytsky, 264 p.

3. Pro zatverdzhennja planu zahodiv z realizacii' Koncepcii' reformuvannja derzhavnoi' systemy pravovoi' ohorony intelektual'noi' vlasnostiv Ukrai'ni [About the Approval of the Plan of Measures to Implement the Concept of Reforming the State System of Legal Protection of Intellectual Property in Ukraine (2016) The Order of the Cabinet of Ministers of Ukraine. Retrieved from https://www.kmu.gov.ua/ua/npas/249287204

4. Statistical information about the state of crime in Ukraine for 2012, 2016-2018. Official website of the Ministry of Internal Affairs of Ukraine. Retrieved from https://mvs.gov.ua/ 